\title{
The Mediating Effect of Time Management on the Relationship Between Knowledge Management and Organization Performance Comparison Between Local $\&$ the International NGOs
}

\author{
Nemer Wahbeh \\ University of Jordan \\ E-mail: n.wahbeh@iaa.edu.jo \\ Hamza M. Mohammed \\ University of Jordan \\ E-mail: hamzasilwady@outlook.com \\ Omar Al Daher \\ University of Jordan \\ E-mail: omar.daher@gmail.com \\ Abdullah Al shatter \\ University of Jordan \\ E-mail: alshatter_sh@yahoo.com
}

Received: September 3, 2016 Accepted: November 10, 2015 Published: December 23, 2016 doi:10.5296/ieb.v2i2.10496

URL: http://dx.doi.org/10.5296/ieb.v2i2.10496

\begin{abstract}
Purpose: The purpose of this paper is to investigate about time management effect on the relationship between knowledge management and organization performance. Design/methodology/approach: The paper contains a comparative analysis of relevant literature from the fields of knowledge management, time management and organization
\end{abstract}




\section{Macrothink}

performance, conducted between 2007 and 2015. The research was conducted on a sample of 42 non-profit organizations (24 National and 18 International) we collected the data through a questionnaire that was given to the Monitoring and development department. Findings: The research results reached to the idea that Time Management really plays a strong role to strengthen the relationship between Knowledge Management and Organization Performance dimensions, but not all dimensions, only the standard dimensions (Internal business process, Learning and growth and the Sustainability), but on the non-standard dimension we used which is: the increase or the decrease on the percentage of the affected population who receive services from the organizations, the result is on the opposite side. Also it reached to the result that the organization nationality affects the relationship between knowledge management and the performance management. Originality/value: The paper ranks among the first to search for convergences between International and National non-profit organizations that seem firmly divided in both theoretical and institutional aspects.

Keywords: Time management, knowledge management, organization performance 


\section{The General Framework}

\subsection{Introduction}

Each one of the three phrases, Knowledge Management, Time Management and Organizational Performance has its importance and focus separately, the majority of the organizations and/or individual professionals pay attention to reach high levels of each. (2)

Combining the three fields -supposedly- will produce advanced results, this is the theoretical assumption we based on in our research, we see the time management as a mediating variable will show a relationship between the knowledge management and the organizational performance. .(2)

The focus will be in the research on the non-profit organizations who work to provide assistance and services to the people who are affected by crisis, we found an interesting addition to our work which is adding the nationality of the organization a moderating variable, the big picture of this variable to see how the national organizations different in term of the work conducted from international organization, and to also see how this will affect the relationship between knowledge management and organizational performance.

We reviewed many researches talking about the knowledge management and measuring it in many ways; we concluded that measuring knowledge management through Knowledge Creation, Knowledge Sharing, knowledge representation and Knowledge Responsiveness. We are focusing on how the process of knowledge management affects the activities and the time management skills, and how effectively time management is involved in achieving performance.

On the other hand, it is a known fact that the financial perspective is one of the core dimensions to measure the majority of the organizational performance, but in our case, since we're focusing on one of the UN organizations which is considered as non-profit organization, we eliminated this dimension.

\subsection{Problem Statement}

As we stated previously, here we are expanding the exposure on how to leverage time management as mediating variable to strengthen the relationship between knowledge management and organization performance, we will answer the following questions for the sake of reach to a conclusion:

A. How to measure knowledge management dimensions in NGOs?

B. How to measure time management dimensions?

C. How to leverage time management dimension to strengthen the relationship between knowledge management utilization approach and organization performance?

D. How to see the results of applying some NGO's key indicators (International and National NGOs) and some other performance indicators and dimensions?

\subsection{Statement of Objectives}




\section{Macrothink}

A. Evaluating the range of using knowledge management techniques in NGOs.

B. Evaluating the range of using Time management techniques in NGOs.

C. Evaluating the Organizational Performance indicators of NGOs programs.

D. Measuring the relation between knowledge management \& organizational Performance.

E. Measuring the impact of time management on the Relation Between using the knowledge management techniques \& organizational Performance in NGOs.

\subsection{Theoretical Background}

In this section we review the relevant literature on time management, knowledge management and organization performance that serves as a theoretical framework of this study.

\subsubsection{Knowledge Management}

Jenny Darroch (2008) analyzed knowledge management as a coordinating mechanism and that a firm with a knowledge management capability will use resources more efficiently and so will be more innovative and perform better. Data were collected using a mail survey sent to CEOs representing firms. and the result supported the important role of knowledge management within firms (Darroch, 2005).

Tatiana Andreeva \& Aino Kianto (2012) evaluated the actual connection between knowledge management activities and organizational outcomes. And they tested with structural equation modeling by using a survey dataset of 234 companies. The results show that knowledge management activities are quite strongly correlated and have a statistically significant influence on both financial performance and competitiveness of the firm. The findings also indicate that knowledge management activities improve financial performance only when information communication technology practices are coupled with human resource management practices (Kianto, 2012).

Ram Manohar Singh Meenakshi Gupta, (2014) researched the role of knowledged in improving firm performance, he suggests that the concept of knowledge management is divided into three instances; development, utilization and capitalization, based on the assumption that knowledge is not always result in improving performance a semi-structured interview was conducted with 24 information technology (IT) professionals. the result was that the link between knowledge and performance often stop with proxies such as productivity, it is evident that although activities always require knowledge, all knowledge is not always used. And even if it is, it might not result in profits (Gupta, 2014).

\subsubsection{Time Management}

Dezhi Wu, Katia Passerini \& Michael R. Bartolacci (2008) conducted a research study on the knowledge workers' individual time management practices. Based on the qualitative analysis, 
the research shows that knowledge workers focus on conditional knowledge of time, and pragmatic knowledge (Wu, Passerini, \& Bartolacci, 2008).

Ahmad Al Khatib (2014) asserted that past researchers have found time management as one of the predictors of performance and achievement. In his study of 352 college students from Al Ain University of Science and Technology, UAE, he found that time management skill level explained 26 percent of total variance in the grade point average (Khatib, 2014).

Shazia Nasrullah \& Muhammad Khan (2015) performed a research to determine the relationship between the time management skills and academic performance of the students. Time management is very important and it may actually affect individual's overall performance and achievements. the data was collected from the students of Qurtuba University of Science and Technology to analyze that how effectively they are managing their time for achieving their academic standards (Nasrullah, \& Saqib Khan, 2015).

Derrick C. Darden (2015) researched the time-wasting activities in organizations to help identify time-wasting behaviors and what to do about them based on information gathered through observations in the workplace and recent research articles on the topic (Darden, 2015).

\subsubsection{Organization Performance}

Andre' A. de Waal (2007) analyzed the strong interest in identifying the characteristics of high performance organizations. This interest has been fired by the rapid changes in the competitive environment of companies. a survey with a sufficient number of respondents was conducted so that its results can be assumed to be fairly representative. From this analysis, he have identified several characteristics that seem to be decisive factors for achieving lasting good performance (De Waal, 2007).0

Amy Tung, Kevin Baird \& Herbert P. Schoch (2011) conducted a research study to examine the association between the use of multidimensional performance measures and four organizational factors with the effectiveness of performance measurement systems. Data were collected by mail survey questionnaire from a random sample of 455 senior financial officers in Australian manufacturing organizations. The results reveal that the use of multidimensional performance measures is associated with two dimensions of the effectiveness of performance measurement systems. The results also reveal that organizational factors were associated with the effectiveness of performance measurement systems (Herbert \& Schoch, 2011).

Andre' de Waal, Robert Goedegebuure and Patricia Geradts (2011) describe the results of a study that explored the quantitative impact of performance management on the results of a non-profit organization. Quantitative performance data of the organization, before and after the introduction of performance management, were collected and linked to key activities and events that occurred in the organization during and after the implementation. The results support managers who want to introduce performance management to improve the results of their non-profit organisation. At the same time, the research indicates that introducing and using performance management needs continuous attention of management in order to become and stay successful in the long run (De Waal \& Hinfelaar, 20150). 


\section{The Theoretical Framework}

Theoretical Framework.

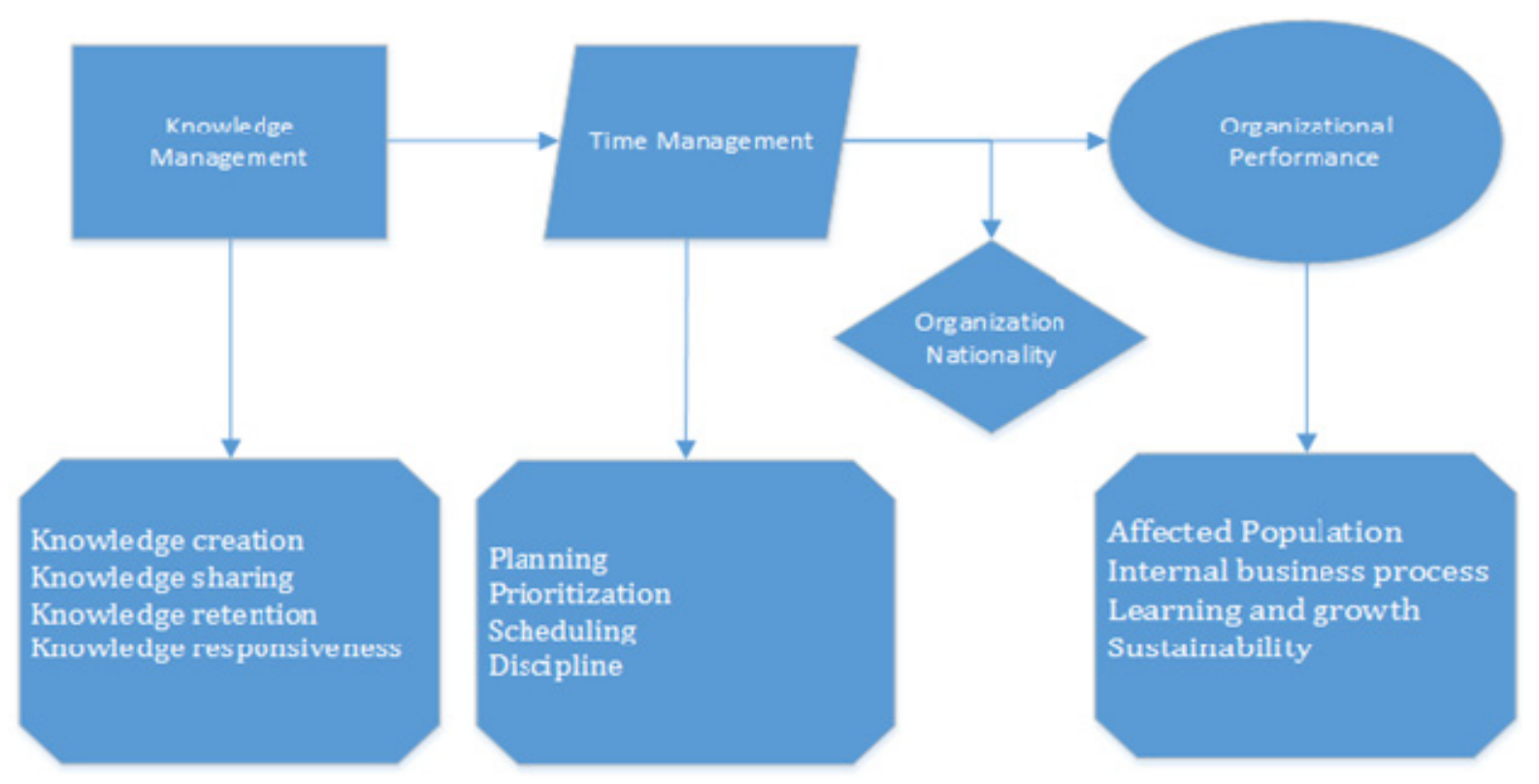

Figure 1. Theoretical FW 1.

Variables Methodology:

\subsection{Dimensions of Knowledge Management}

Given the critical role of knowledge management in organizations, various perspectives have emerged on knowledge management, knowledge creation, knowledge sharing, and knowledge absorptive. In a recent attempt to compile works on knowledge management, Nonaka (2005) classified the studies under 12 themes that included diverse disciplinary perspectives such as economics, psychology and strategic management, in this study0; we will measure knowledge management from the perspective of organizational behavior. As is often the case with developing concepts, several overlapping definitions have been proposed for different facets of knowledge management. Our review reveals that there is many concepts have been developed substantively in literature. In our view, these concepts can be categorized into four main dimensions of knowledge management (De Waal \& Hinfelaar, 20150).

\subsubsection{Knowledge Creation}

Concepts relating to knowledge creation focus on the process by which "new" knowledge is created and assimilated into the functioning of the organization, and if there is a mechanisms for creating and acquiring knowledge from different source (Gupta, 2014).

\subsubsection{Knowledge Sharing}

Concepts relating to knowledge sharing are concerned with the process by which existing 
knowledge is shared and disseminated within the organization, and if there is a mechanism for transferring the acquired knowledge from the customers feedback, business partners, learned lessons.

\subsubsection{Knowledge Retention}

Knowledge retention concepts focus on the process by which knowledge is retained and passed on within the organization in the form of group memory ,documents or routines, and if there is a mechanisms for storing the data \& using the information technology to store \& retrieve the knowledge (Gupta, 2014, Kalling, 2003).

\subsubsection{Knowledge Responsiveness}

Knowledge responsiveness concept is focus on the utilizing \& using this Knowledge (Kalling, 2003).0

\subsection{Dimensions of Time Management}

The effectual utilizing of time and managing time requires procedures and good planning behaviors. One can make use of time effectively and competently by time saving techniques and behaviors, they can be categorized into numerous groups and contribute to a number of fundamental qualities in general. Viktoriya Varlamova (2008) analyzes the subdivision of time management into five; Planning, Priority setting, Goal setting, Time allocation and Scheduling. Hassanzabeh \& A.G. Ebadi (2007) Categorize six time management dimensions; Goal setting, Planning, Prioritizing, Decision-making, Delegating and Scheduling.0.

And in this research we will categorize time management dimensions into four surfaces; Planning, Prioritization, Scheduling and Discipline

Planning: Means managing goals and tasks, long-range objectives and short-range activities. to have control on daily and weekly structure and having disciplined routines. Managing these tasks and goals will ensure that a person do not forget any important errands or miss any deadlines.

Prioritization: Prioritizing is your ability to see what tasks are more important at each moment and give those tasks more of your attention, energy, and time. This is an essential part of efficient time management as this would allow you to do the tasks that actually matter the most to you (Nasrullah, \& Saqib Khan, 2015).

\subsubsection{Scheduling}

It's the art of planning your activities so that you can achieve your goals and priorities in the time you have available. Therefore knowing when they had to state no to activities to avoid taking on more than you can handle, and achieve a good work-life balance (Varlamova, 2008).

\subsubsection{Discipline}

Effective management of time means having the discipline to actually act on your plan. Discipline determines the actual implementation of your plans. A good follow-up is also 
necessary so old tasks or projects are not forgotten. There are new things to do each day that might need much attention to manage all of these tasks0.

\subsection{Dimensions of Organization Performance}

On the other researches, there are many dimensions to measure the organization's performance, including but not limited to: Financial perspective, Customer perspective, internal business process perspective, Learning and growth perspective and Sustainability 0. As we are aiming to focus on the organization performance for NGOs, and as it's known that NGOs of the UN agencies which is considered a non-profit organization; we eliminated the financial dimension from the set of the variables we use to measure the performance (De Waal \& Hinfelaar, 20150).

On the other hand, the customer satisfaction dimension is different in its nature in our research context. There is no customers with non-profit organizations, the people who receive the services are called "Beneficiaries", and since NGOs is currently working to provide its services to the people who are affected by Syria crisis, both: the Syrian refugees and the host communities, so we replaced the term customer to be "Affected Population" (De Waal, 2007).

To measure the affected population satisfaction in the traditional way, it will be long and complicated process. We selected a more practical approach to do the measurement. We will look at NGOs indicators through Monitoring and Evaluation lenses, especially those who are related to measure the quality of services delivered to the affected population (Hassanzabeh \& Ebadi, 2007).

However, the following are the dimension we used to measure the performance for NGOs in Jordan, during its mission to provide the services to the affected population (Herbert \& Schoch, 2011):0

\subsubsection{Affected Population}

Percentage of affected population benefited from the provided services.

Growth on the percentage over time.

Quality of provided services through NGOs KPIs.

Internal business process:

Productivity.

Clear processes and procedures.

\subsubsection{Learning and Growth}

Hours of training provided.

Improvements made to employee facilities.

Number of employee suggestions implemented.

\subsubsection{Sustainability}


Investment in environmental management.

Investment in community services.

Community connectedness services.

\subsection{Hypothesis}

H-01 There is no relationship between the knowledge management and Affected Population.

H-02 There is no relationship between the knowledge management and internal business process.

H-03 There is no relationship between the knowledge management and Learning and growth.

H-04 There is no relationship between the knowledge management and Sustainability.

H-05 Time management has no mediating effect on the relationship between knowledge management and Affected Population.

H-06 Time management has no mediating effect on the relationship between knowledge management and internal business process.

H-07 Time management has no mediating effect on the relationship between knowledge management and Learning and growth.

H-08 Time management has no mediating effect on the relationship between knowledge management and Sustainability.

H-09 Organization nationality has no moderating effect on the relationship between knowledge management and Organizational Performance.

\section{Research Methodology}

\subsection{Research Population and Sample}

Research population consist of ALL NGOs (national \& international) that work in Jordan, Research sample is a simple random sample consists of 10 national NGOs \& 10 international.

\subsection{Data Collection Methods}

In order to achieve the objectives of this research a questionnaire was developed and distributed among the population of the research which consisted of (20) subjects, (100) valid responses were collected, thus, forming a response rate of $(85.47 \%)$.

\subsection{Data Analysis Methods}

Data obtained from the instrument was then statistically analyzed the program [Statistical Package for Social Science (SPSS)] to answer the research questions and to test the research hypotheses.

\subsection{Validity and Reliability Tests}

\subsubsection{Validity Test}


A questionnaire was developed; in order to test validity of instrument; to make sure that its measure what it intended to measure according to the principle of face validity, and then presented to few professors in the college of Business Administration in order to judge it. This instrument was modified as much as possible based on their opinions and suggestions.

\subsubsection{Reliability Test}

In order to test the reliability of the instrument we used Cronbach alpha test and it is found that $\alpha=87.5 \%$ which is good because it is greater than accepted $60 \%$.

\subsection{Time Frame of the Research}

This research was implemented in 2016 as a partial requirement to success in the subject of research business methods, and it took three months of practice, and has used the descriptive analytical research methodology to achieve the desired results.

\section{Statistical Analyze}

\subsection{Organization Nationality}

Table 1. Describing the organization nationality

\begin{tabular}{llll}
\hline Variable & Category & n & \% \\
\hline Organization Nationality & International & 18 & 42.9 \\
& national & 24 & 57.1 \\
& Total & 42 & 100 \\
\hline
\end{tabular}

\subsection{Reliability Analysis Results}

Table 2. Reliability analysis results for the dimensions of knowledge management, time management, and organization performance using cronbach alpha

\begin{tabular}{llll}
\hline No. & Dimension & No. of items & reliability \\
\hline 1 & Knowledge Management & 23 & 0.970 \\
2 & Time Management & 14 & 0.957 \\
3 & Affected Population & 9 & 0.623 \\
& Sustainability & 4 & 0.794 \\
& Learning and growth & 2 & 0.640 \\
& Internal business process & 4 & 0.907 \\
& organization performance & 19 & 0.819 \\
\hline
\end{tabular}

The values provided in table (2) tell that dimensions reflect a very good reliability. The values ranged between (0.623) for Affected Population and (0.970) for Knowledge Management.

All the provided reliability values reflect a high and good reliability (as the greatest value 
could be is 1.00$)$.

4.3 Descriptive Analysis

Table 3. means and standard deviations, FI and skewness for the knowledge management, time management, and organization performance

\begin{tabular}{llllll}
\hline No. & Dimensions & Mean & SD & FI & Skewness \\
\hline 1 & Knowledge Management & 3.53 & 0.78 & 70.6 & -.470 \\
2 & Time Management & 3.47 & 0.87 & 69.4 & -.611 \\
3 & Affected Population & 3.43 & 0.33 & 68.6 & .128 \\
& Sustainability & 3.63 & 0.50 & 72.6 & -.225 \\
& Learning and growth & 3.89 & 0.88 & 77.8 & -.079 \\
& Internal business process & 3.43 & 1.01 & 68.6 & -.508 \\
& Organization performance & 3.59 & 0.55 & 71.8 & -.699 \\
\hline
\end{tabular}

Table 3 indicates the values of means and standard deviation, FI for the knowledge management, time management, and organization performance. Knowledge management was rated by a mean of (3.53) while time management was rated by a mean of (3.47); the organization performance was rated by a mean of (3.59).

The organization performance was addressed by Learning and growth by a mean of (3.89) as the highest mean while the organization performance was addressed by both the affected population and internal business process as the least mean (3.43).

The following tables show the descriptive analysis for the items in each dimensions of knowledge management:

4.3.1 Analyzing Knowledge Management

Table 4. Means, standard deviations and FI for items of knowledge management

\begin{tabular}{|c|c|c|c|c|c|}
\hline No. & Items & Mean & SD & FI & Rank \\
\hline 19 & $\begin{array}{l}\text { The organization has regular symposiums, lectures, } \\
\text { Conferences, and training sessions to share Knowledge. }\end{array}$ & 4.00 & 1.01 & 80.0 & 1 \\
\hline 1 & $\begin{array}{l}\text { The organization has mechanisms for creating and acquiring } \\
\text { knowledge from different sources. }\end{array}$ & 3.93 & 0.26 & 78.6 & 2 \\
\hline 2 & $\begin{array}{l}\text { The organization has processes for the exchange of } \\
\text { knowledge between individuals and groups. }\end{array}$ & 3.86 & 0.84 & 77.2 & 3 \\
\hline 11 & $\begin{array}{l}\text { The organization gives feedback to employees on their ideas } \\
\text { and knowledge. }\end{array}$ & 3.79 & 0.68 & 75.8 & 4 \\
\hline 17 & $\begin{array}{l}\text { The organization sends out timely reports with appropriate } \\
\text { information to employees. }\end{array}$ & 3.79 & 0.95 & 75.8 & 4 \\
\hline
\end{tabular}


5 The organization responses to employees ideas and 3.71

0.89

documents them for further development.

8 The organization has policies in place to allow employees to 3.71 present new ideas without fear.

18 The organization has libraries, resource center and other 3.64 forums to display knowledge.

6 The organization has mechanisms in place to transfer 3.57 knowledge from employees into the organization.

$7 \quad$ The organization has mechanisms for converting knowledge 3.57 into action plans.

9 The organization has a policy to review knowledge on a 3.57 regular basis.

12 The organization has processes for applying knowledge 3.57 learned from experiences.

20 The organization has different methods for employees to further develop their knowledge and apply them to any situation.

21 The organization has mechanisms to protect knowledge from inappropriate or illegal use inside and outside of the Organization.

23 The organization has methods to analyze and critically evaluate knowledge to generate new patterns and knowledge for future use.

4 The organization has mechanisms for creating new knowledge from existing knowledge.

22 The organization applies knowledge to critical competitive needs and quickly links sources of knowledge in problem solving.

13 The organization utilizes databases and information technology applications to store knowledge for easy access by all employees.

3 The organization rewards employees for new ideas.

10 The organization has mechanisms for filtering different

3.21

0.87

64.2

20 sources and types of knowledge.

14 The Organization utilizes various written devices such as newsletter, manuals to store the knowledge they captured from employees.

15 The organization has different publications to display the 3.21 captured knowledge.

16 The organization has mechanisms to patent and copyright $\begin{array}{lllll}2.86 & 1.20 & 57.2 & 23\end{array}$ new knowledge.

knowledge management

$3.53 \quad 0.78 \quad 70.6$


Table 4 indicates the values of means and standard deviation, FI for the knowledge management. Item no. (19) Which states that "The organization has regular symposiums, lectures, Conferences, and training sessions to share Knowledge." has ranked the first order by a mean of (4.00) while item no. (16) Which states that "The organization has mechanisms to patent and copyright new knowledge." has ranked the least by a mean (2.86)

The knowledge management mean was (3.53).

\subsubsection{Analyzing Time Management}

Table 5. Means, standard deviations and FI for items of Time management

\begin{tabular}{llllll}
\hline No. & Items & Mean & SD & FI & Rank \\
\hline 10 & The organization employees keep a list of things to do. & 3.93 & 0.46 & 78.6 & 1 \\
8 & The organization sets long-term goals. & 3.79 & 1.02 & 75.8 & 2 \\
11 & The organization employees write reminder notes. & 3.71 & 0.71 & 74.2 & 3 \\
2 & The organization has mechanism to review activities. & 3.64 & 1.12 & 72.8 & 4 \\
4 & The organization is prioritizing the tasks. & 3.64 & 1.30 & 72.8 & 4 \\
7 & The organization sets short-term goals. & 3.64 & 0.98 & 72.8 & 4 \\
13 & The organization employees organize paper works. & 3.50 & 0.99 & 70.0 & 7 \\
3 & The organization has standards in setting deadlines for each task. & 3.36 & 1.36 & 67.2 & 8 \\
6 & The organization has standards for breaking down complex & 3.29 & 1.04 & 65.8 & 9 \\
& tasks. & & & & 9 \\
9 & The organization employees carry appointment books and Keep & 3.29 & 1.17 & 65.8 & 9 \\
& a daily log. & & & & 11 \\
1 & The organization has mechanism for evaluating daily tasks. & 3.21 & 1.02 & 64.2 \\
5 & The organization has policies in setting priorities for tasks. & 3.21 & 1.34 & 64.2 & 11 \\
14 & The organization has mechanisms to schedule wasted time. & 3.21 & 1.16 & 64.2 & 11 \\
12 & The organization has policies to avoid interruptions that waste & 3.14 & 1.14 & 62.8 & 14
\end{tabular}

Table 5 indicates the values of means and standard deviation, FI for the Time management. Item no. (10) Which states that "The organization employees keep a list of things to do." has ranked the first order by a mean of (3.93) while item no. (12) Which states that "The organization has policies to avoid interruptions that waste time." has ranked the least by a mean (3.14)

The Time management mean was (3.47).

\subsubsection{Analyzing Organization Performance Dimensions}


Table 6. Means, standard deviations and FI for organization performance elements

\begin{tabular}{|c|c|c|c|c|c|c|}
\hline No. & Items & & Mean & $\mathrm{SD}$ & FI & Rank \\
\hline 3 & Learning and growth & & 3.89 & 0.88 & 77.8 & 1 \\
\hline 2 & Sustainability & & 3.63 & 0.50 & 72.6 & 2 \\
\hline 1 & Affected Population & & 3.43 & 0.33 & 68.6 & 3 \\
\hline \multirow[t]{2}{*}{4} & Internal business process & & 3.43 & 1.01 & 68.6 & 3 \\
\hline & & Performance Organization & 3.59 & 0.55 & 71.8 & \\
\hline
\end{tabular}

Table 6 indicates the values of means and standard deviation, FI for the organization performance elements. Learning and growth has ranked the first order by a mean of (3.89) while both affected population and internal business process has ranked the least by a mean (3.43)

The performance organization mean was (3.59).

Analyzing the elements of the organization performance according to the items:

\subsubsection{Analyzing Affected Population Dimension}

Table 7. Means, standard deviations and FI for items of affected population

\begin{tabular}{|c|c|c|c|c|c|}
\hline No. & Items & Mean & $\mathrm{SD}$ & FI & Rank \\
\hline 6 & $\begin{array}{l}\text { Number of children enrolled in formal education is } \\
\text { maintained or increased comparing with the last academic } \\
\text { year. }\end{array}$ & 3.71 & 0.81 & 74.2 & 1 \\
\hline 4 & $\begin{array}{l}\text { The number of individuals trained on child protection } \\
\text { increased comparing with last year. }\end{array}$ & 3.64 & 0.62 & 72.8 & 2 \\
\hline 1 & $\begin{array}{l}\text { The structured, sustained child protection or psychosocial } \\
\text { support programmers covers more children in need } \\
\text { comparing with last year. }\end{array}$ & 3.57 & 0.74 & 71.4 & 3 \\
\hline 12 & $\begin{array}{l}\text { The number of beneficiaries with access to an adequate } \\
\text { quantity of safe water is increasing. }\end{array}$ & 3.57 & 0.63 & 71.4 & 3 \\
\hline 2 & $\begin{array}{l}\text { The number of children who are receiving specialized child } \\
\text { protection services increased comparing with last year. }\end{array}$ & 3.50 & 0.74 & 70.0 & 5 \\
\hline 9 & $\begin{array}{l}\text { Non-formal education (as alternative education path for out } \\
\text { of public schools children who are not eligible for formal } \\
\text { education) is enhanced comparing with the last academic } \\
\text { year. }\end{array}$ & 3.50 & 0.74 & 70.0 & 5 \\
\hline 10 & $\begin{array}{l}\text { The number of children under } 5 \text { years fully covered with } \\
\text { routine Immunization antigens forms acceptable percentage } \\
\text { of in need children. }\end{array}$ & 3.14 & 0.35 & 62.8 & 7 \\
\hline 11 & $\begin{array}{l}\text { The number of emergency affected people vaccinated for } \\
\text { measles forms acceptable percentage of in need children. }\end{array}$ & 3.14 & 0.35 & 62.8 & 7 \\
\hline
\end{tabular}


13 The number of beneficiaries who have experienced a 3.07

hygiene promotion session is increasing.

affected population $\quad 3.43 \quad 0.33 \quad 68.6$

Table 7 indicates the values of means and standard deviation, FI for the affected population. Item no. (6) Which states that "Number of children enrolled in formal education is maintained or increased comparing with the last academic year." has ranked the first order by a mean of (3.71) while item no. (13) Which states that "The number of beneficiaries who have experienced a hygiene promotion session is increasing." has ranked the least by a mean (3.07)

The affected population mean was (3.43).

4.3.5 Analyzing Sustainability Dimension

Table 8. Means, standard deviations and FI for items of sustainability

\begin{tabular}{|c|c|c|c|c|c|}
\hline No. & Items & Mean & SD & FI & Rank \\
\hline 3 & $\begin{array}{l}\text { Informal education covers acceptable percentage of } \\
\text { children, youth and adolescents who are ineligible for } \\
\text { formal education comparing with last year. }\end{array}$ & 3.71 & 0.46 & 74.2 & 1 \\
\hline 4 & $\begin{array}{l}\text { The Investment in environmental management continuously } \\
\text { maintained. }\end{array}$ & 3.64 & 1.19 & 72.8 & 2 \\
\hline 1 & $\begin{array}{l}\text { Teachers, facilitators and school staff training covers more } \\
\text { beneficiaries comparing with the last academic year. }\end{array}$ & 3.57 & 0.74 & 71.4 & 3 \\
\hline \multirow[t]{2}{*}{2} & $\begin{array}{l}\text { Life skills based education covers acceptable percentage of } \\
\text { children, youth and adolescents who are ineligible for } \\
\text { formal education comparing with last year. }\end{array}$ & 3.57 & 0.63 & 71.4 & 3 \\
\hline & sustainability & 3.63 & 0.50 & 72.6 & \\
\hline
\end{tabular}

Table 8 indicates the values of means and standard deviation, FI for sustainability. Item no. (3) Which states that "Informal education covers acceptable percentage of children, youth and adolescents who are ineligible for formal education comparing with last year." has ranked the first order by a mean of (3.71) while item no. (1) Which states that "Teachers, facilitators and school staff training covers more beneficiaries comparing with the last academic year." And item no. (2) Which states "Life skills based education covers acceptable percentage of children, youth and adolescents who are ineligible for formal education comparing with last year." has ranked the least by a mean (3.57) for each

The sustainability mean was (3.63).

4.3.6 Analyzing Learning and Growth Dimension 
Table 9. Means, standard deviations and FI for items of Learning and growth

\begin{tabular}{llllll}
\hline No. & Items & Mean & sd & FI & Rank \\
\hline 2 & When that is required, the employees are prepared to take & 4.14 & 0.75 & 82.8 & 1 \\
& $\begin{array}{r}\text { additional efforts and work } \\
1\end{array}$ & & & & \\
& The Improvements made to employee facilities maintained. & 3.64 & 1.30 & 72.8 & 2 \\
& Learning and growth & 3.89 & 0.88 & 77.8 & \\
\hline
\end{tabular}

Table 9 indicates the values of means and standard deviation, FI for Learning and growth. Item no. (2) Which states that "When that is required, the employees are prepared to take additional efforts and work" has ranked the first order by a mean of (4.14) while item no. (1) Which states that "The Improvements made to employee facilities maintained." has ranked the least by a mean (3.64)

The Learning and growth mean was (3.89).

\subsubsection{Analyzing Internal Business Process Dimension}

Table 10. Means, standard deviations and FI for items of Internal business process

\begin{tabular}{llllll}
\hline No. & Items & Mean & sd & FI & Rank \\
\hline 3 & In our organization vision, mission \& Goals is clear for all & 3.79 & 1.34 & 75.8 & 1 \\
& staff \\
4 & In our organization the internal Standard Operating & 3.57 & 0.99 & 71.4 & 2 \\
& Procedures (SOPs) is always maintained \& developed & & & \\
2 & In our organization innovative practices are rewarded & 3.21 & 1.09 & 64.2 & 3 \\
& accordingly & & & \\
& In our organization good work is rewarded accordingly & 3.14 & 1.14 & 62.8 & 4 \\
& Internal business process & 3.43 & 1.01 & 68.6 \\
\hline
\end{tabular}

Table 10 indicates the values of means and standard deviation, FI for Internal business process. Item no. (3) Which states that "In our organization vision, mission \& Goals is clear for all staff" has ranked the first order by a mean of (3.79) while item no. (1) Which states that "In our organization good work is rewarded accordingly" has ranked the least by a mean (3.14)

The Learning and growth mean was (3.43).

\subsubsection{Correlation Matrix}


Table 11. Correlation matrix among the variables

\begin{tabular}{|c|c|c|c|c|c|c|c|c|}
\hline & index & $\begin{array}{l}\text { Knowledge } \\
\text { Management }\end{array}$ & $\begin{array}{l}\text { Time } \\
\text { Management }\end{array}$ & $\begin{array}{l}\text { Affected } \\
\text { Population }\end{array}$ & Sustainability & $\begin{array}{l}\text { Learning } \\
\text { and growth }\end{array}$ & $\begin{array}{l}\text { Internal business } \\
\text { process }\end{array}$ & performance \\
\hline Knowledge & $\mathrm{R}$ & 1 & $0.970^{* *}$ & 0.100 & $0.622^{* *}$ & $0.815^{* *}$ & $0.964^{* *}$ & $0.923^{* *}$ \\
\hline Management & Sig & & 0.000 & 0.529 & 0.000 & 0.000 & 0.000 & 0.000 \\
\hline Time & $\mathrm{R}$ & & 1 & -0.026 & $0.619^{* *}$ & $0.831^{* *}$ & $0.966^{* *}$ & $0.911^{* *}$ \\
\hline Management & Sig & & & 0.870 & 0.000 & 0.000 & 0.000 & 0.000 \\
\hline Affected & $\mathrm{R}$ & & & 1 & $0.316^{*}$ & -0.020 & 0.015 & 0.221 \\
\hline Population & Sig & & & & 0.041 & 0.900 & 0.926 & 0.160 \\
\hline \multirow[t]{2}{*}{ Sustainability } & $\mathrm{R}$ & & & & 1 & $0.547^{* *}$ & $0.653^{* *}$ & $0.793^{* *}$ \\
\hline & Sig & & & & & 0.000 & 0.000 & 0.000 \\
\hline Learning & $\mathrm{R}$ & & & & & 1 & $0.821^{* *}$ & $0.896^{* *}$ \\
\hline growth & Sig & & & & & & 0.000 & 0.000 \\
\hline Internal business & $\mathrm{R}$ & & & & & & 1 & $0.937^{* *}$ \\
\hline process & Sig & & & & & & & 0.000 \\
\hline \multirow[t]{2}{*}{ performance } & $\mathrm{R}$ & & & & & & & 1 \\
\hline & Sig & & & & & & & \\
\hline
\end{tabular}

The correlation coefficients between the KM and performance was observed to be high (0.923), between the mediator and performance also was high (0.911).

The relationship between the independent and mediator variable was high (0.970).

The relationship among the elements of dependent variable was ranging between weak $(0.015)$ between affected population and internal business process and high $(0.821)$ between learning and growth and internal business process.

These results indicate that there is an acceptable range of overlapping between the independent variables and the mediator variable being used to estimate the relationships of mediations and at the same time acceptable range of relationships among the elements of the dependent variable (performance).

\subsection{Hypothesis Testing}

Prior to start testing the hypothesis the researcher checks for one main assumptions concerning application of linear regression, normality distribution of the independent variable. The results were included in table (3)

\subsubsection{Hypothesis Testing: $\mathrm{H}-01$}

There is no relationship between the knowledge management and Affected Population.

Table 12. Simple linear regression for testing the relationship between the knowledge management and Affected Population

\begin{tabular}{lllllllll}
\hline Relation direction & $\mathrm{r}$ & $\mathrm{R}^{2}$ & $\mathrm{~F}$ & $\mathrm{Sig}(\mathrm{f})$ & $\beta$ & $\mathrm{t}$ & $\mathrm{Sig}(\mathrm{t})$ & Constant \\
\hline $\begin{array}{c}\text { knowledge management on } \\
\text { affected population }\end{array}$ & 0.100 & 0.010 & 0.40 & 0.529 & 0.042 & 0.63 & 0.529 & 3.279 \\
\hline
\end{tabular}

According to the results of simple linear regression of knowledge management does not 


\section{Macrothink}

affect Affected Population as the f value (0.40) was not significant (0.529).

The beta coefficient reflects the effect value in the prediction model. It was (0.042) not significantly contributes to affected population as the probability of $t$ statistics was $(0.529)>$ than 0.05 . The $t$ statistics tests the linearity importance of the beta coefficient obtained for the independent variable.

The value of R2 expresses the prediction strength of the dependent variable using the independent variable it was found to be $(1.0 \%)$ and this value also may be viewed as the variation percentage in the dependent variable that can be accounted for the independent variable.

As a result the null hypothesis is accepted and the alternative one is rejected.

\subsubsection{Hypothesis Testing H-02}

There is no relationship between the knowledge management and Internal business process.

Table 13. Simple linear regression for testing the relationship between knowledge management and internal business process

\begin{tabular}{lllllllll}
\hline Relation & $\mathrm{r}$ & $\mathrm{R}^{2}$ & $\mathrm{~F}$ & $\mathrm{Sig}(\mathrm{f})$ & $\beta$ & $\mathrm{t}$ & $\mathrm{Sig}(\mathrm{t})$ & Constant \\
\hline $\begin{array}{c}\text { knowledge management } \\
\text { on internal process }\end{array}$ & 0.964 & 0.930 & 528.64 & 0.000 & 1.247 & 22.99 & 0.000 & -0.977 \\
\hline
\end{tabular}

According to the results of simple linear regression of knowledge management affects internal business process as the f value $(0.000)$ was significant $(0.000)$.

The beta coefficient reflects the effect value in the prediction model. It was (1.247) significantly contributes to Internal business process as the probability of $t$ statistics was $(0.000)<$ than 0.05 . The $t$ statistics tests the linearity importance of the beta coefficient obtained for the independent variable.

The value of R2 expresses the prediction strength of the dependent variable using the independent variable it was found to be $(93.0 \%)$ and this value also may be viewed as the variation percentage in the dependent variable that can be accounted for the independent variable.

As a result the null hypothesis is rejected and the alternative one is accepted.

\subsubsection{Hypothesis Testing H-03}

There is no relationship between the knowledge management and Learning and growth. 


\section{Macrothink}

Table 14. Simple linear regression for testing the relationship between knowledge management and Learning and growth

\begin{tabular}{lllllllll}
\hline Relation & $\mathrm{r}$ & $\mathrm{R}^{2}$ & $\mathrm{~F}$ & $\mathrm{Sig}(\mathrm{f})$ & $\beta$ & $\mathrm{t}$ & $\operatorname{Sig}(\mathrm{t})$ & Constant \\
\hline $\begin{array}{c}\text { knowledge management on } \\
\text { learning and growth }\end{array}$ & 0.815 & 0.665 & 79.32 & 0.000 & 0.915 & 8.90 & 0.000 & 0.659 \\
\hline
\end{tabular}

According to the results of simple linear regression of knowledge management affects Learning and growth as the f value (79.32) was significant (0.000).

The beta coefficient reflects the effect value in the prediction model. It was (0.915) significantly contributes to Learning and growth as the probability of $t$ statistics was $(0.000)$ $<$ than 0.05 . The $t$ statistics tests the linearity importance of the beta coefficient obtained for the independent variable.

The value of R2 expresses the prediction strength of the dependent variable using the independent variable it was found to be $(66.5 \%)$ and this value also may be viewed as the variation percentage in the dependent variable that can be accounted for the independent variable.

As a result the null hypothesis is rejected and the alternative one is accepted.

\subsubsection{Hypothesis Testing H-04}

There is no relationship between the knowledge management and Sustainability.

Table 15. Simple linear regression for testing the knowledge management and Sustainability

\begin{tabular}{lllllllll}
\hline Relation & $\mathrm{r}$ & $\mathrm{R}^{2}$ & $\mathrm{~F}$ & $\mathrm{Sig}(\mathrm{f})$ & $\beta$ & $\mathrm{t}$ & $\mathrm{Sig}(\mathrm{t})$ & $\mathrm{Constant}$ \\
\hline $\begin{array}{c}\text { knowledge } \\
\text { sustainability }\end{array}$ & & & & & & & & \\
\hline
\end{tabular}

According to the results of simple linear regression of knowledge management affects Sustainability as the f value (24.25) was significant (0.000).

The beta coefficient reflects the effect value in the prediction model. It was $(0.400)$ significantly contributes to Sustainability as the probability of $t$ statistics was $(0.000)<$ than 0.05. The $t$ statistics tests the linearity importance of the beta coefficient obtained for the independent variable.

The value of R2 expresses the prediction strength of the dependent variable using the independent variable it was found to be $(38.7 \%)$ and this value also may be viewed as the variation percentage in the dependent variable that can be accounted for the independent variable. 
As a result the null hypothesis is rejected and the alternative one is accepted. The idea of mediating variable is proposed to increase the relationship between an independent variable affecting a dependent variable. The mediation effect of a variable on another is measured by the indirect effect (the effect caused by the mediating variable). In path analysis the indirect effect is the multiplication of the path weights.

\subsubsection{Hypothesis Testing H-05}

Time management has no mediating effect on the relationship between knowledge management and Affected Population.

Table 16. Path analysis for testing the mediating effect of Time management on the relationship between knowledge management and Affected Population

\begin{tabular}{llllllll}
\hline Path & $\mathrm{r}$ & $\mathrm{R}^{2}$ & $\mathrm{~F}$ & $\mathrm{Sig}(\mathrm{f})$ & $\beta$ & $\mathrm{t}$ & $\mathrm{Sig}(\mathrm{t})$ \\
\hline KM on TM & 0.970 & 0.942 & 646.25 & 0.000 & 1.073 & 25.42 & 0.000 \\
TM on affected population & 0.026 & 0.001 & 0.027 & 0.870 & -0.010 & -0.16 & 0.870 \\
KM on affected population & 0.100 & 0.010 & 0.40 & 0.529 & 0.042 & 0.63 & 0.529 \\
\hline
\end{tabular}

Based on the results presented in table (16) the path weight between knowledge management and time management was (1.073) and that the path weight between the time management and affected population was (-0.010), so the indirect effect is $(-0.010)$.

The total effect is given by adding the indirect effect to the direct effect between the independent and dependent variable which was (0.042).

The result of total effect is (0.031). As could be figured out the effect of mediation of Time management decreased the total effect by the mediation value.

As a result the null hypothesis is rejected and the alternative one is accepted.

\subsubsection{Hypothesis Testing H-06}

Time management has no mediating effect on the relationship between knowledge management and internal process.

Table 17. Path analysis for testing the mediating effect of Time management on the relationship between knowledge management and internal process

\begin{tabular}{llllllll}
\hline Path & $\mathrm{r}$ & $\mathrm{R}^{2}$ & $\mathrm{~F}$ & $\mathrm{Sig}(\mathrm{f})$ & $\beta$ & $\mathrm{t}$ & $\mathrm{Sig}(\mathrm{t})$ \\
\hline KM on TM & 0.970 & 0.942 & 646.25 & 0.000 & 1.073 & 25.42 & 0.000 \\
TM on internal process & 0.966 & 0.934 & 566.42 & 0.000 & 1.130 & 23.80 & 0.000 \\
KM on internal process & 0.964 & 0.930 & 528.64 & 0.000 & 1.247 & 22.99 & 0.000 \\
\hline
\end{tabular}


Based on the results presented in table (17) the path weight between knowledge management and time management was (1.073) and that the path weight between the time management and internal process was (1.130), so the indirect effect is (-1.212).

The total effect is given by adding the indirect effect to the direct effect between the independent and dependent variable which was (1.247). The result of total effect is (2.459). As could be figured out the effect of mediation of Time management increased the total effect by the mediation value.

As a result the null hypothesis is rejected and the alternative one is accepted.

\subsubsection{Hypothesis Testing H-07}

Time management has no mediating effect on the relationship between knowledge management and learning growth.

Table 18. Path analysis for testing the mediating effect of Time management on the relationship between knowledge management and learning growth

\begin{tabular}{llllllll}
\hline Path & $\mathrm{r}$ & $\mathrm{R}^{2}$ & $\mathrm{~F}$ & $\mathrm{Sig}(\mathrm{f})$ & $\beta$ & $\mathrm{t}$ & $\mathrm{Sig}(\mathrm{t})$ \\
\hline KM on TM & 0.970 & 0.942 & 646.25 & 0.000 & 1.073 & 25.42 & 0.000 \\
TM on learning growth & 0.831 & 0.691 & 89.35 & 0.000 & 0.844 & 9.45 & 0.000 \\
KM on learning growth & 0.815 & 0.665 & 79.32 & 0.000 & 0.915 & 8.90 & 0.000 \\
\hline
\end{tabular}

Based on the results presented in table (18) the path weight between knowledge management and time management was (1.073) and that the path weight between the time management and learning growth was $(0.844)$, so the indirect effect is $(0.906)$

The total effect is given by adding the indirect effect to the direct effect between the independent and dependent variable which was (0.915). The result of total effect is (1.821). As could be figured out the effect of mediation of Time management increased the total effect by the mediation value.

As a result the null hypothesis is rejected and the alternative one is accepted.

\subsubsection{Hypothesis Testing H-08}

Table 19. Path analysis for testing the mediating effect of Time management on the relationship between knowledge management and sustainability

\begin{tabular}{llllllll}
\hline Path & $\mathrm{r}$ & $\mathrm{R}^{2}$ & $\mathrm{~F}$ & $\mathrm{Sig}(\mathrm{f})$ & $\beta$ & $\mathrm{T}$ & $\mathrm{Sig}(\mathrm{t})$ \\
\hline KM on TM & 0.970 & 0.942 & 646.25 & 0.000 & 1.073 & 25.42 & 0.000 \\
TM on sustainability & 0.619 & 0383 & 27.87 & 0.000 & 0.000 & 4.98 & 0.000 \\
KM on sustainability & 0.622 & 0.387 & 25.24 & 0.000 & 0.000 & 5.02 & 0.000 \\
\hline
\end{tabular}




\section{Macrothink}

Issues in Economics and Business

ISSN 2377-2301

2016, Vol. 2, No. 2

Time management has no mediating effect on the relationship between knowledge management and sustainability.

Based on the results presented in table (19) the path weight between knowledge management and time management was (1.073) and that the path weight between the time management and sustainability was $(0.000)$, so the indirect effect is $(0.000)$.

The total effect is given by adding the indirect effect to the direct effect between the independent and dependent variable which was (0.000).

The result of total effect is $(0.000)$. As could be figured out the effect of mediation of Time management increased the total effect by the mediation value.

As a result the null hypothesis is rejected and the alternative one is accepted.

\subsubsection{Hypothesis Testing H-09}

Organization nationality has no moderating effect on the relationship between knowledge management and organization performance.

Table 20. Path analysis for testing the moderation effect of organization nationality on the relationship between Time management and organization performance

\begin{tabular}{llllllll}
\hline Organization nationality & $\mathrm{r}$ & $\mathrm{R}^{2}$ & $\mathrm{~F}$ & $\operatorname{Sig}(\mathrm{f})$ & $\beta$ & $\mathrm{t}$ & $\operatorname{Sig}(\mathrm{t})$ \\
\hline International & 0.952 & 0.906 & 153.69 & 0.000 & 0.541 & 12.39 & 0.000 \\
National & 0.986 & 0.972 & 766.91 & 0.000 & 0.881 & 27.69 & 0.000 \\
\hline
\end{tabular}

Table 20 shows that the value of $\mathrm{R} 2$ for the national organization $(97.2 \%)$ was greater than the international $(90.6 \%)$. It was observed the effect value in the case of national organization was $(0.881)$ which was greater than the effect value for the international organizations (0.541).

The related probabilities of the significance of effect values were statistically significant as the related probability was less than $0.05(0.000)$ and (0.000) respectively.

The results tell that the organization nationality moderates the relationship between time management and organization performance such that it becomes better in the national organizations

Upon these results the null hypothesis is rejected and the alternative one is accepted.

\section{Conclusions and Recommendations}

\subsection{Conclusions}

A. The increasing and decreasing of affected population doesn't depend on the knowledge management, but when time management intervenes in the relationship between them. And our research shows that the time management didn't create a 
relationship between the knowledge management and the percentage affected population it affect the relationship in a negative way.

B. There is a statistically significant relationship between knowledge management and the organization performance dimensions (Internal business process, Learning and growth And Sustainability). And there is a statistically significant mediating effect of time management between knowledge management and the mentioned dependent variables.

C. There is a statistically significant impact on the moderating effect of organization nationality between the independent variable and the dependent variable; that national organizations are better in utilizing the knowledge management than international organizations, due to the size, complexity of the hierarchy and the long chain of command affect organization performance.

\subsection{Recommendations}

Based on previous conclusions, the research recommends the following:

A. As we found that Time Management really plays a strong role as a mediating variable to strengthen the relationship between Knowledge Management and Organization Performance dimensions, we recommend paying more attention on time management factors.

B. On the other hand, one of the interesting results we reached from our statistical analysis is that there's no relationship between knowledge management and increasing or decreasing the percentage of affected population benefiting from the services, and time management affect the relationship between the knowledge management and the percentage affected population in a negative way, we see that this as interesting topic for more researches.

C. Also another interesting result from our research is that national organizations is better in utilizing the knowledge management to increase organization performance, we think that the size of the organizations plays a role in this relationship, and this is also another interesting topic for a new research.

\section{References}

Darden, D. (2015). Time Wasting Activities within the Workplace: Don't Be A part of Them. Open Journal of Business and Management, 3, 345-348.

Darroch, J. (2005). Knowledge management, innovation and firm performance. Journal of Knowledge Management, 9(3), 101-115.

De Waal, A., \& Hinfelaar, R. (2015). Developing a scale for measuring high performance partnerships. Journal of Strategy and Management, 8(1), 87-108.

De Waal, A. (2007). The characteristics of a high performance organization. Business Strategy Series, 8(3), 79-185.

Gupta, R. (2014). Knowledge management in teams: empirical integration and development of a scale. Journal of Knowledge Management, 18(4), 777-794. 


\section{Macrothink}

Issues in Economics and Business

ISSN 2377-2301

2016, Vol. 2, No. 2

Herbert, A. H. \& P. Schoch (2011). Factors influencing the effectiveness of performance measurement systems. International Journal of Operations \& Production Management, 31(12), 1287-1310.

Kalling, T. (2003). Knowledge management and the occasional links with performance. Journal of Knowledge Management, 7(3), 67-81.

Khatib, A. (2014). e Management and Its Relation to Students' Stress, Gender and Academic Achievement among Sample of Students at Al Ain University of Science and Technology. International Journal of Business and Social Research, 4(5).

Kianto, T. (2012). Does knowledge management really matter? Linking knowledge management practices, competitiveness and economic performance. Journal of Knowledge Management, 16(4), 617-636.

Nasrullah, S., \& Saqib Khan, M. (2015). The Impact of Time Management on the Students' Academic Achievements. Journal of Literature, Languages and Linguistics, 11.

Hassanzabeh, R., \& Ebadi, A. G. (2007). Measure the Share of the Effective Factors and Time Management. World Applied Sciences Journal, 2(3), 168-174.

Varlamova, V. (2008). The Relationship between Time Management and Decision-Making Processes. Master theses' University of Canterbury August 2008.

Wu, D., Passerini, K., \& Bartolacci, M. (2008). By When Do You Need This Done? Discovering Knowledge Workers'. 


\section{Appendices}

Questionnaire (Please answer the following statements)

Questions that measure Knowledge Management:

\begin{tabular}{|c|c|c|c|c|c|c|}
\hline \# & Statement & $\begin{array}{r}\text { Strongly } \\
\text { Agree }\end{array}$ & Agree & Neutral & Disagree & $\begin{array}{l}\text { Strongly } \\
\text { Disagree }\end{array}$ \\
\hline 1 & $\begin{array}{l}\text { The organization has mechanisms for } \\
\text { creating and acquiring knowledge from } \\
\text { different sources. }\end{array}$ & & & & & \\
\hline 2 & $\begin{array}{l}\text { The organization has processes for the } \\
\text { exchange of knowledge between } \\
\text { individuals and groups. }\end{array}$ & & & & & \\
\hline 3 & $\begin{array}{l}\text { The organization rewards employees for } \\
\text { new ideas. }\end{array}$ & & & & & \\
\hline 4 & $\begin{array}{l}\text { The organization has mechanisms for } \\
\text { creating new knowledge from existing } \\
\text { knowledge. }\end{array}$ & & & & & \\
\hline 5 & $\begin{array}{l}\text { The organization responses to employees } \\
\text { ideas and documents them for further } \\
\text { development. }\end{array}$ & & & & & \\
\hline 6 & $\begin{array}{l}\text { The organization has mechanisms in } \\
\text { place to transfer knowledge from } \\
\text { employees into the organization. }\end{array}$ & & & & & \\
\hline 7 & $\begin{array}{l}\text { The organization has mechanisms for } \\
\text { converting knowledge into action plans. }\end{array}$ & & & & & \\
\hline 8 & $\begin{array}{l}\text { The organization has policies in place to } \\
\text { allow employees to present new ideas } \\
\text { without fear. }\end{array}$ & & & & & \\
\hline 9 & $\begin{array}{l}\text { The organization has a policy to review } \\
\text { knowledge on a regular basis. }\end{array}$ & & & & & \\
\hline 10 & $\begin{array}{l}\text { The organization has mechanisms for } \\
\text { filtering different sources and types of } \\
\text { knowledge. }\end{array}$ & & & & & \\
\hline 11 & $\begin{array}{l}\text { The organization gives feedback to } \\
\text { employees on their ideas and knowledge. }\end{array}$ & & & & & \\
\hline 12 & $\begin{array}{l}\text { The organization has processes for } \\
\text { applying knowledge learned from } \\
\text { experiences. }\end{array}$ & & & & & \\
\hline 13 & $\begin{array}{l}\text { The organization utilizes databases and } \\
\text { information technology applications to } \\
\text { store knowledge for easy access by all } \\
\text { employees. }\end{array}$ & & & & & \\
\hline 14 & The Organization utilizes various written & & & & & \\
\hline
\end{tabular}




\section{Macrothink}

Issues in Economics and Business

ISSN 2377-2301

2016, Vol. 2, No. 2

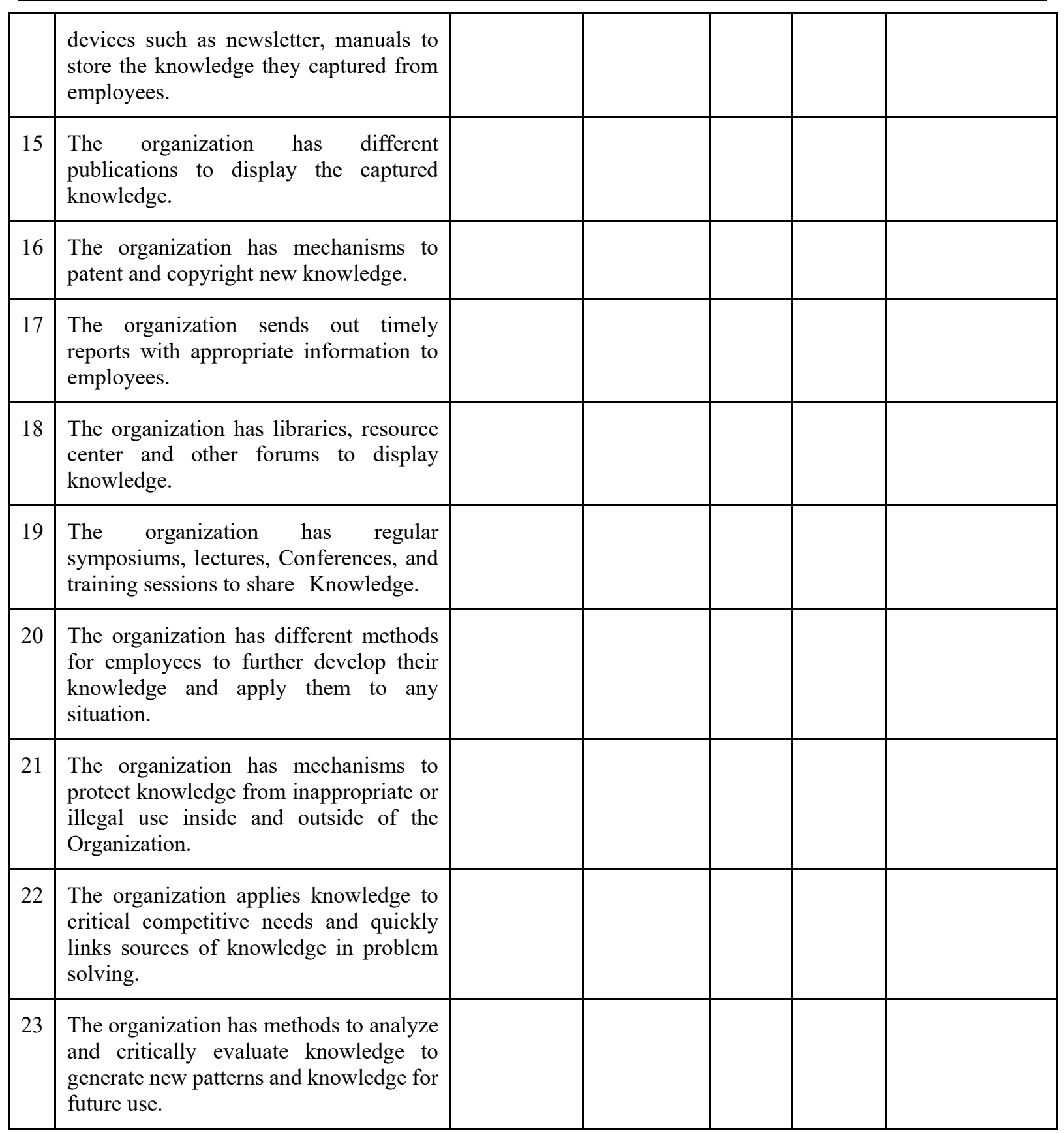

Questions that measure Time Management:

\begin{tabular}{|l|l|l|l|l|l|l|}
\hline$\#$ & Statement & $\begin{array}{r}\text { Strongly } \\
\text { Agree }\end{array}$ & Agree & Neutral & Disagree & $\begin{array}{r}\text { Strongly } \\
\text { Disagree }\end{array}$ \\
\hline 1 & $\begin{array}{l}\text { The organization has mechanism for } \\
\text { evaluating daily tasks. }\end{array}$ & & & & & \\
\hline 2 & $\begin{array}{l}\text { The organization has mechanism to } \\
\text { review activities. }\end{array}$ & & & & & \\
\hline 3 & The organization has standards in setting & & & & & \\
\hline
\end{tabular}




\section{Macrothink \\ Issues in Economics and Business \\ ISSN 2377-2301 \\ 2016, Vol. 2, No. 2}

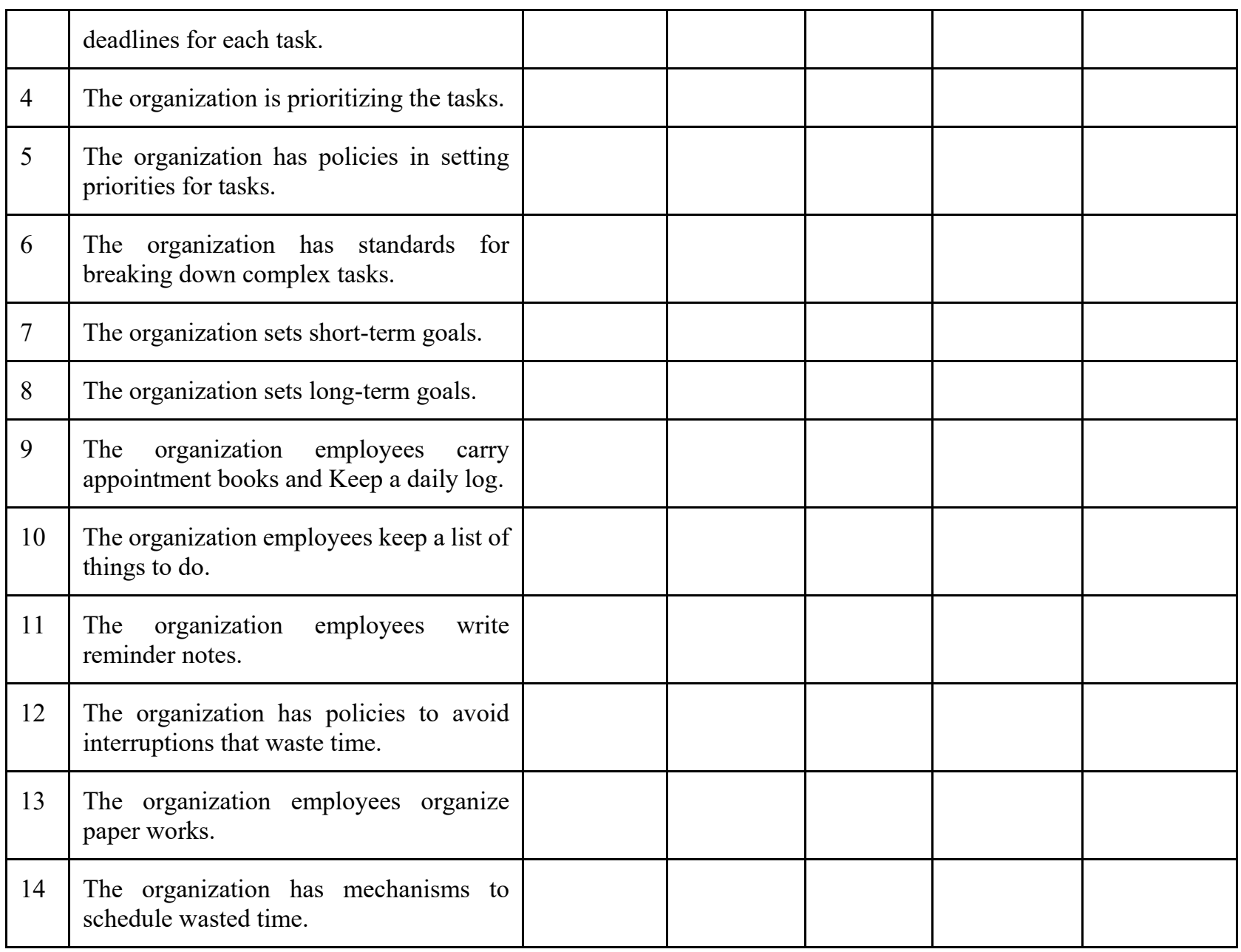

Questions that measure Organization Performance:

Please answer based on the Percentage :
○ Strongly Agree $\quad 80-100 \%$
- Agree
$60-79 \%$
○ Neutral
$40-59 \%$
- Disagree
$20-39 \%$

- Strongly Disagree

Less Than $20 \%$

\begin{tabular}{|l|l|r|l|l|l|l|}
\hline$\#$ & Statement & $\begin{array}{r}\text { Strongly } \\
\text { Agree }\end{array}$ & Agree & Neutral & Disagree & $\begin{array}{r}\text { Strongly } \\
\text { Disagree }\end{array}$ \\
\hline 1 & $\begin{array}{l}\text { Number of children enrolled in formal } \\
\text { education is maintained or increased } \\
\text { comparing with the last academic year. }\end{array}$ & & & & & \\
\hline
\end{tabular}




\begin{tabular}{|c|c|c|c|c|c|c|}
\hline 2 & $\begin{array}{l}\text { non-formal education is enhanced an } \\
\text { alternative education path for out of public } \\
\text { schools children who are not eligible for } \\
\text { formal education comparing with the last } \\
\text { academic year. }\end{array}$ & & & & & \\
\hline 3 & $\begin{array}{l}\text { Teachers, facilitators and school staff } \\
\text { training covers more beneficiaries } \\
\text { comparing with the last academic year. }\end{array}$ & & & & & \\
\hline 4 & $\begin{array}{l}\text { Life skills based education covers } \\
\text { acceptable percentage of children, youth } \\
\text { and adolescents who are ineligible for } \\
\text { formal education comparing with last } \\
\text { year. }\end{array}$ & & & & & \\
\hline 5 & $\begin{array}{l}\text { Informal education covers acceptable } \\
\text { percentage of children, youth and } \\
\text { adolescents who are ineligible for formal } \\
\text { education comparing with last year. }\end{array}$ & & & & & \\
\hline 6 & $\begin{array}{l}\text { The structured, sustained child protection } \\
\text { or psychosocial support programs covers } \\
\text { more children in need comparing with last } \\
\text { year. }\end{array}$ & & & & & \\
\hline 7 & $\begin{array}{l}\text { The number of children who are receiving } \\
\text { specialized child protection services } \\
\text { increased comparing with last year. }\end{array}$ & & & & & \\
\hline 8 & $\begin{array}{l}\text { The number of individuals trained on } \\
\text { child protection increased comparing with } \\
\text { last year. }\end{array}$ & & & & & \\
\hline 9 & $\begin{array}{l}\text { The number of beneficiaries with access } \\
\text { to an adequate quantity of safe water is } \\
\text { increasing. }\end{array}$ & & & & & \\
\hline 10 & $\begin{array}{l}\text { The number of beneficiaries who have } \\
\text { experienced a hygiene promotion session } \\
\text { is increasing. }\end{array}$ & & & & & \\
\hline 13 & $\begin{array}{l}\text { The number of children under } 5 \text { years } \\
\text { fully covered with routine Immunization } \\
\text { antigens forms acceptable percentage of } \\
\text { in need children. }\end{array}$ & & & & & \\
\hline 14 & $\begin{array}{l}\text { The number of emergency affected people } \\
\text { vaccinated for measles forms acceptable } \\
\text { percentage of in need children. }\end{array}$ & & & & & \\
\hline 15 & $\begin{array}{l}\text { The Improvements made to employee } \\
\text { facilities maintained. }\end{array}$ & & & & & \\
\hline 16 & $\begin{array}{l}\text { The Investment in environmental } \\
\text { management continuously maintained. }\end{array}$ & & & & & \\
\hline
\end{tabular}




\section{Copyright Disclaimer}

Copyright for this article is retained by the author(s), with first publication rights granted to the journal. This is an open-access article distributed under the terms and conditions of the Creative Commons Attribution license (http://creativecommons.org/licenses/by/3.0/). 